\title{
地震マグニチュードの物理的基礎
}

東北大学理学部地球物理学教室 小山順二・島 田 伸介

(昭和 60 年 4 月 7 日受理)

\section{Physical Basis of Earthquake Magnitudes}

\author{
Junji Koyama and Nobusuke Shimada
}

Geophysical Institute, Faculty of Science, Tohoku University

(Received April 7, 1985)

A relation between surface-wave magnitude $M_{s}$ and fault area $S$ for great earthquakes has been proposed;

$$
\log S \simeq 2 M_{s}-11.5 \quad\left(M_{s}>7.5\right) .
$$

A similar formula has been also derived for body-wave magnitude $m_{b}{ }^{*}$ redetermined from maximum amplitudes of short-period P-wave trains;

$\log S \propto 1.7 m_{b}^{*}$.

These are quite different from a theoretical relation expected on the basis of long wave approximation. The statistical theory of extreme values has been applied to understand the relations considering that the component waves which consititute the wave trains for $m_{b} *-M_{s}$ determinations originate from the random fracture of fault heterogeneities.

\section{§1.はじめに}

地震マグニチュードは地震の大きさやエネルギーを表わす量として, 古くから広く使われて きた [GUTENBERG and RICHTER (1954)]. 近地で観測される比較的小さな地震のマグニチュ ードは個々の観測組織が独自にさまざまな方法で決定し，局地的な地震活動を評価している [AdAMs (1977); BÅTh (1981); LeE and WeTMILleR (1978)].

地震の発生過程が物理的に記述され, 地震モーメントや断層規模などによつて, 定量的に地 震の大きさが表現されるようになつてきた[例えば，KANAMORI and ANDERSRN (1975); PURUCARU and BERCKHEMER (1982)]. それにしたがい，混乱しているマグニチュードスケー ルを統一しようとする考学があり [GELLER and KANAMORI (1977); CHRISTOSKOV et al. (1979); ABE and KANAMORI (1980)], 大さい地震ばかりではなく, 広いダイナミックレンジ にわたり地震マグニチュードが統一的に評価されるようになつてきた。

従来, 経験量としてのみ取りあつかわれている地震マグニチュードに関する統計式も, 震源 パラメータとの関連や時系列解析の進んだ理論をもとに，それらの見なおしもなされつつある [小山・武村 (1983)]. 本稿では, 主に短波長近似のもとで地震マグニチュードと震源パラメー 


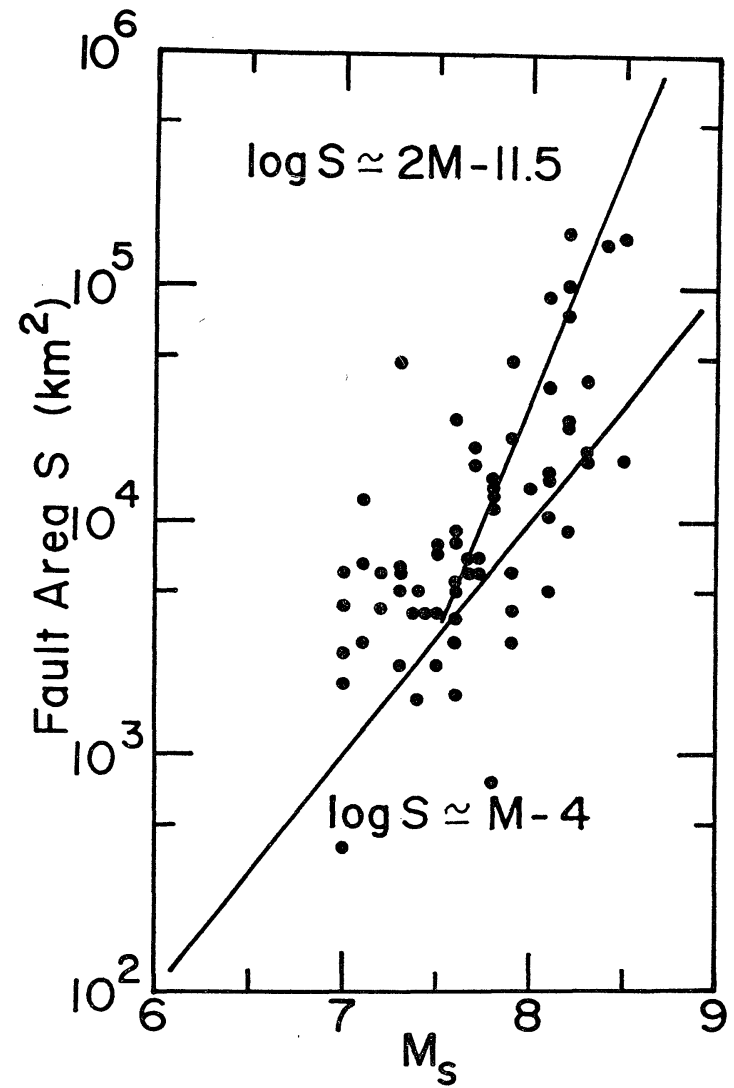

Fig. 1. Relations between surface-wave magnitude $M_{s}$ and fault area $S$ for large and great earthquakes (Reproduced from KoYAMA and ZHENG, 1985). $M_{s}$ 's are quoted from ABE $(1981,1984)$ and $S$ 's from LAY et al. (1982). So-called Utsu-Seki formula fits the data of earthquakes with $M_{s}$ 's smaller than 7 (KANAMORI and ANDERSON, 1975), while a new relation $\log S \simeq 2 M-11.5$, fits the data of earthquakes with $M_{s}$ 's larger than 7.5 .
タがどのような関係になるのかを極值 統計の立場から考えてみよう。

§2. 地震マグニチュード, 断層面 積, 地震モーメント

表面波マグニチュード $M_{s}$ は遠地の 地震記象に卓越する周期 20 秒前後の 表面波振幅から決められる。 GUTENBERG and RICHTER (1954) 以後, こ のマグニチュードスケールも混乱の際 に達していたが，GELLER and KANAMORI (1977) やABE (1981, 1984) の 一連の研究で凡そ一世紀にわたる主要 地震の規模評価が統一的になされたこ とになる. KOYAMA and ZHENG (1985) はこの表面波マグニチュードを巨大地 震の断層面積, 余震面積, 津波浪源域 面積と比較して (Fig. 1),

$$
\log \mathrm{S} \simeq 2 M_{s}-11.5\left(M_{s}>7.5\right)
$$

を得た。この式は従来知られていた宇 津・関公式 (1954);

$$
\log S \simeq M-4
$$

とは大きく違う関係式である。ただし $S$ の単位は $\mathrm{km}^{2}$ である.

KANAMORI and ANDERSON (1975) は, 20 秒周期の表面波最大振幅が震 源スペクトルの周期 20 秒での強度に 依存すると考光, $M_{s}$ と地震モーメン トや断層の長さ $L$ との関係を決定論 的に記述し， 4 つの場合に分類した。

すなわち，周期 20 秒を基準にしたとき，(a) 断層面上のすべり時間 $\tau$ が短く, 破壊の伝播継 続時間 $T_{L}$ が長い場合, (b) $\tau$ が長く, $T_{L}$ が短い場合, (c) $\tau$ も $T_{L}$ も長い場合, (d) $\tau$ も $T_{L}$ も短い場合である。（a）は細長い断層破壞の地震，(b) は津波地震のようなゆつくりしたすべ りの地震，(c) は非常に大きな地震，(d) は微小地震と近似的に考光られょう. GUTENBERG and RICHTER (1954) のエネルギーと $M_{s}$ の関係;

$$
\log E_{s}=1.5 M_{s}+11.8
$$

や，地震モーメント， $M_{0}$ と $M_{s}$ との関係式;

$$
\log M_{0} \propto 1.5 M_{s}
$$


は, 地震の発生過程が, 上述の (a) や (b) の場合として, これら (3), (4) 式が理解されてき た [KANAMMORI and ANDERSON (1975)]. 理論的にも経験的にも,

$$
M_{0} \propto S^{3 / 2}
$$

が示される，従つて，(1) 式の関係は，(3) や (4) 式から期待される $M_{s}$ と $S$ の関係と異な るものであると云えよう.

実体波マグニチュード $m_{b}$ は，近地地震の解析に使われたり，観測系の歴史的变遷などもあ り, “Misunderstanding and oversimplified misapplications" [SPALL (1980)] が指摘されて いる. 武村・小山 (1980) は大地震の短周期地震波の励起を調べる為, 世界標準地震計短周期 記録を用いて，P波々群の最大振幅から実体波マグニチュード $m_{b}$ * の再決定を行つた．小山 等 $(1984)$ はこの $m_{b}$ *を用いて, 短周期地震モーメント $M_{1}$ との関係式;

$$
\log M_{1}=1.24 m_{b} *+17.9
$$

を得た。をた，短周期地震モーメント は，データのばらつきは大きいが，平 均的に見て, 長周期地震波がら独立に 決められる地震モーメントと

$$
M_{0} \propto M_{1}^{2}
$$

の関係にあることを指摘した。

Fig. 2 で小山等 (1984) のデータか ら $M_{0}$ と $m_{b}$ *を比較し, (6) と (7) 式 から,

$$
\log M_{0} \simeq 2.48 m_{b}^{*}+11.1
$$

なる関係を得る，津波地震のデータ等 も含み, 又, 地震活動域が凡世界的に 広いことなどのため，データのばらつ きは大きいが，(8) 式が良く観測值を 説明していることがわかる。ただし，

(8) 式は厳密な最小自乗法の結果では ない.これは, Fig. 2 のデータが $m_{0}$ *の 6.5 から 7.0 に集中して分布 している為, 最小自乗解はそれらのデ 一タに強く支配されるから用いないの である. 巨大地震の数は少ないが，震 源過程を考える上からは，非常に重要 であることは云らまでもなく（8）式 のように巨大地震のデータに大きな重 みをおく関係式を採用している。(5) 式を用いると，近似式；

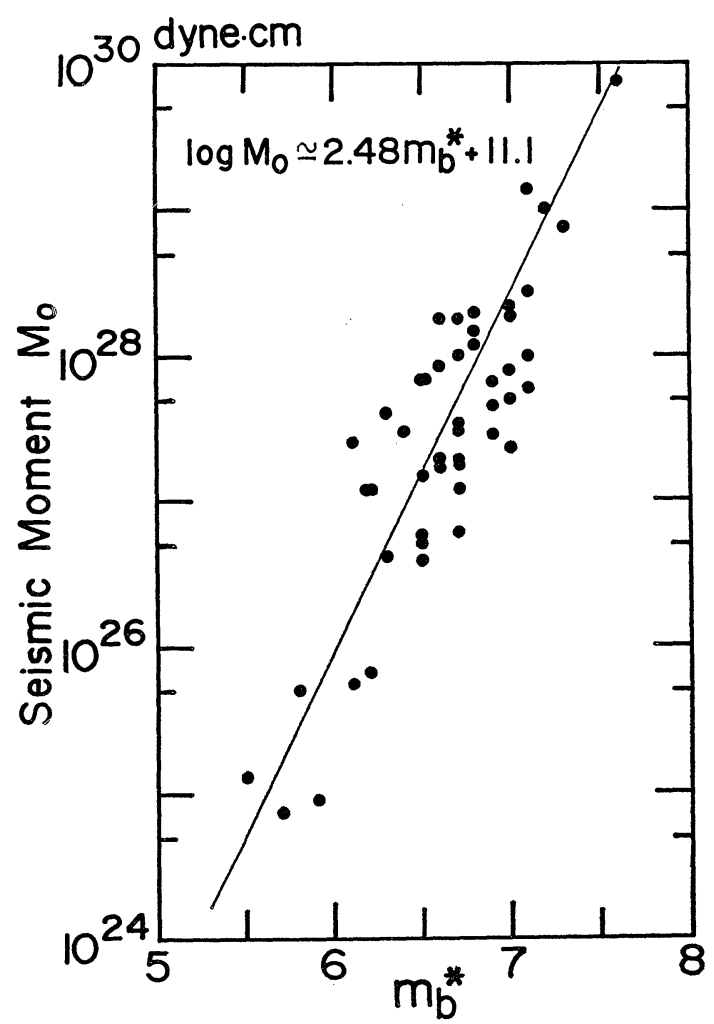

Fig. 2. Relation between body-wave magnitude $m_{b} *$ redetermined by TAKEMURA and KoYAMA (1980) and seismic moment $M_{0}$ by LAY et al. (1982). The relation, $\log M_{0} \simeq$ $2.48 m_{b} *+11.1$, is inferred from KoYAMA and ZHENG (1985). This relation is used to derived $\log S \propto 1.7 m_{b} *$ from an assumption of $M_{0} \propto S^{3 / 2}$ where $S$ is fault area. 
が求まる.このように短周期地震波の励起を反映する実体波マグニチュードも断層破壊全体の 大きさと密接に関係している， $m_{b}{ }^{*}$ は周期が和およそ $1 \sim 2$ 秒の短周期 $\mathrm{P}$ 波々形から決められ ている [武村・小山(1980)]。ここでは島孤帯で発生する浅発地震を考えているのであるから， $m_{b}$ *を規定している地震波の波長は打拉よそ $10 \mathrm{~km}$ 程度であろう. (9) 式を導くに用いた地 震は 1964 年アラスカ地震等の巨大地震であり, 断層の長さは数十 $\mathrm{km}$ から数百 $\mathrm{km}$ 以上に も及ぶ.このように $m_{b}$ * は地震の大きさに比べて短波長の波動で決まり, その時の $S$ と $m_{b}$ * の関係 $\left[(9)\right.$ 式] は， $M_{s}$ と $S$ との関係で云えば，(2) 式よりは，はるかに (1) 式の関係に近い.

この様に, $M_{s}>7.5$ の巨大地震の表面波マグニチュードや短波長近似が成立しているような 実体波マグニチュード $m_{b}$ * から，各々の波動最大振幅は掠およと断層面積の平方根に比例し ているようである.

\section{§3. 極值統計による最大振幅}

KANAMORI AND ANDERSON (1975) は, 地震学的に得られる種々の経験式や統計的表現を 地震発生過程の上から長波長近似, 長周期近似の手法で決定論的に明らかにしている. (2) 式 の宇津・関公式も (4) と（5）式からその物理的意味付けがなされている.ここでは，(1)や (9) 式の物理的意味をそれとは独立に, 確率論的な立場から考えてみよう.

周期 20 秒の表面波といえども, その波長は有限で, $70 \sim 80 \mathrm{~km}$ 程度である. 断層の長さで 云えば, $M_{s} \sim 7.5$ の地震が丁度同程度の規模であろう [AKI (1972)]. 従つて, 1960 年 Chile 地震のように断層破壊が $800 \mathrm{~km}$ にも及ぶような場合 [KANAMORI and CIPAR (1974)], $M_{s}$ は $m_{b}$ *がそうであるのと同様に, 地震の断層規模から見て相対的に短波長の波動の振幅から 決まつていると考觉られる。

短周期地震波の励起は, 近年, 小山 (1983) によつて詳しく考察され, 不均質断層の確率論 的破壞に強く依存すると考えられている：今，断層面上に不均質領域（断層パッチ）が無数に 存在していて，それがランダムに破壞するとしょう．そのようにして励起される波動を遠方で， 例えば周期 1 秒や 20 秒の地震波で観測したとしよう. それらの波動はランダムな断層パッチ の破壞により励起されるものであるから，波の位相はランダムなものになつていると考劣られ る.

この様に考えれば，短波長近似の上で考觉られる地震マグニチュードは，その定義からして， ランダムな位相を持つ波動が確率論的に重ね合わさつた時できる時系列の最大振幅值の常用対 数で与えられるであろう. 最大振幅の最確值 (mode) $a_{\max }$ は, ランダム波動の包絡線振幅の 自乗平均の平方根 (root mean square) $\bar{a}$ を用いて理論的に [LONGUET-HIGGINS (1952)],

$$
a_{\max }=\bar{a} F(N)
$$

と与えられる.ただし，Fは，包絡線振幅の確率分布に依存し，また，時系列実現値大ささの $N$ の関数となる. 波動のスペクトルが狭帯域で, 確率分布が Rayleigh 分布の時, LonguetHIGGINS (1952) は,

$$
F(N)=(\ln N)^{1 / 2}
$$

で表わせることを示した。 
波動のスペクトルが有色になると，Rayleigh 分布は次第に正規分布に漸近し， GUMBEL (1958) は正規分布となる極限で,

$$
F(N)=\left(\ln N^{2} / 2 \pi\right)^{1 / 2}
$$

を導いている. 彼はもつと一般的にこの問題を取り扱い指数分布やロジスティック分布のとき，

$$
F(N)=C \ln N
$$

となることを示した．ただし，Cは確率分布で決まる定数である.

理論的には包絡線振幅の確率分布が知れると $\bar{a} か ゙ 2$ 次のモーメントから計算される. しかし， 我々は, この確率分布を厳密に知つている訳ではない, したがつて, 先ずランダムな断層パッ

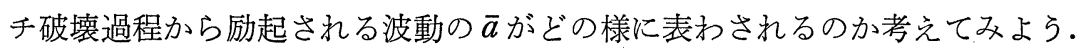

\section{§4. 不均質断層破壊による短周期波動}

断層パッチのランダムな破壊をショットノイズで代表させ，各断層パッチが放出する波動を 観測系の特性も含めて, 減衰振動するサンイ波で近似する時, そのエネルギースペクトルは, サイン波の特徵的な周期 $T_{0}$ で鋭いピークをもつ [小山等 (1984)]:

$$
E\left(T_{0}\right) \propto \overline{r^{2}} k \sigma T_{0}{ }^{3}
$$

ただし， $\boldsymbol{r}^{2}$ はここでは断層パッチが放出する波動の自乗平均振幅と考えればよく，断層面の不 均質性に強く依存するパラメータである，k弾位時間当たりのショットノイズ数（断層パッ チの破壊数）である．また， $\sigma$ は観測される波形の包絡線振幅の拡がりを示すパラメータであ る.

断層面積を $S$, 単位面積当たりの断層パッチ数密度を $m$ とすれば, 断層パッチの総数 $K$ は

$$
K=m S
$$

だから，断層破壊の有効継続時間を $T$ とすれば,

$$
k=K / T
$$

と表わされる. 平均破壊伝播速度 $v_{r}$ を考えれば， $T$ は断層の長さを $v_{r}$ で割つた量で近似さ れるから [KANAMORI and ANDERSON (1975)],

$$
T \simeq S^{1 / 2} / v_{r}
$$

したがつて,

$$
k \simeq m v_{r} S^{1 / 2}
$$

が得られる。

また， $\sigma$ を震源で地震波々動を励起している特徵的な継続時間であると思えば，凡そ，

$$
\sigma \simeq T /(2 \sim 4) \quad \text { or } \quad S^{1 / 2} /(2 \sim 4) v_{r}
$$

で近似されるだろう，さらに（7）式と（14）式から [小山等 (1984)],

$$
M_{0} \propto M_{1}^{2} \propto E\left(T_{0}\right)
$$

の関係を用いると, $\overline{r^{2}}$ は, (5) 式より 


$$
\overline{r^{2}} \propto S^{1 / 2} / m
$$

なる比例関係にある．この式の意味は後で考えることにする.

(14) 式の様に鋭いピークを持つスペクトルの場合は, Parseval の等式をつかつて自乗平均 振幅 $\overline{a^{2}}$ は,

$$
\begin{aligned}
\overline{a^{2}} & \propto E\left(T_{0}\right) / T \\
& \propto S
\end{aligned}
$$

となる．結局，断層パッチのランダムな破壊による短周期波動の最大振幅は，

$$
a_{\mathrm{max}} \propto(K / m)^{1 / 2} F(K)
$$

となることが期待される.

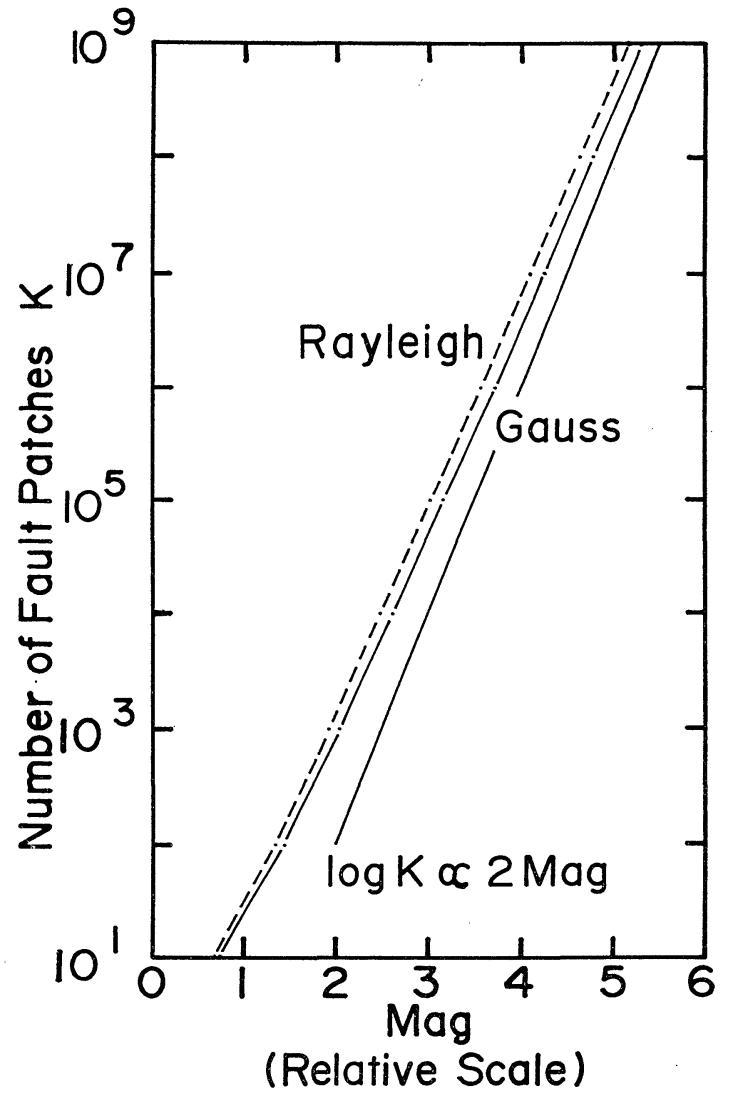

Fig. 3. Hypothetical magnitude scale $M_{a g}$ from statististics of extreme values assuming Rayleigh distribution and Gauss distribution. They are illustrated by broken lines connecting points in the figure, respectively. A line with $\log K \propto 2 M_{a g}$ represents an approximate formula for the above two relations.

\section{$\S 5$. 結 論}

海洋表面の波動はいろいろな波源か らの波が様々な方向から到来し，ラン ダムに重なり合いその波高分布は Rayleigh 分布となる [LONGUETHIgGINS (1952); ANG and TANG (1975)]. 小山等 (1984) は巨大地震が 励起した短周期 $\mathrm{P}$ 波々群の包絡線は䛊 差関数で近似されることを示した。こ れは波高分布を指定している訳ではな いが，(23) 式の $F(K)$ の関数型を制約 する一条件となるだろら。もちろん， 正規波高分布が唯一解である訳でなく， 小山等 (1984) は考慮していないが， Rayleigh 分布関数を巨大地震の短周 期波群の包絡線としても正規分布関数 に近い良い近似になることが期待され る.したがつて,ここでは, (11) と (12) 式を採用して議論を進めることにしよ う。これは震源で励起される波動が単 一周期であつたとしても，減衰の影響 等が帯域を有色化する為であろう.

地震マグニチュードは，観測される 地震波最大振幅を震源から観測点への 波動伝播の影響を補正し，常用対数を 取つた值と定義されている。(23) 式 を用いて，仮想マグニチュードを

$$
\begin{aligned}
M_{a g} & =\log a_{\max } \\
& =1 / 2 \log K+\log F(K)+C_{0}
\end{aligned}
$$


と仮定しょう。ただし， $C_{0}$ は断層パッチの数密度, 平均的大きさから決まる量であるが, ここ では, 簡単のため, 地震の大きさに依存しない $(C o=0)$ と仮定しょう.

Fig. 3 に断層パッチ総数をパラメータにして, 正規分布, Rayleigh 分布の各々の場合につ いて，マグニチュード $M_{a g}$ を示した. 図から明らかなように，K>50 の充分数多く断層パッ チが破壊する場合は, (24) 式右辺第 2 項の影響は小さく, 総パッチ数の対数はマグニチュード の 2 倍に比例している.これは，(15) 式から断層面積の対数はマグニチュードの 2 倍に比例す ることになり, Fig. 1 で示した観測值や Fig. 2 から求められる関係を良く説明している.

(24) 式を見てわかるように, 波高の頻度分布がここで考えた正規分布や Rayleigh 分布で ない場合でも，Kが充分大きければ上に述べた結論は変わらないことが容易に理解される.

CARTWRIGHT and LONGUET-HIGGINS (1956) は (12) 式に代わる近似表現として,

$$
F(N)=\left[\ln \left(N^{2} / 2 \pi\right)-\ln \ln \left(N^{2} / 2 \pi\right)\right]^{1 / 2}
$$

を導いている. GUMBEL (1958) によれば, (25) 式は (12) 式より良い近似となつている.この 場合でも，先と同様に，(24）式右辺第 2 項の影響は小さいから，同じ結論を得る.

\section{§6. 考察と議論}

巨大地震の表面波マグニチュードと断層面積の関係を統一化されたマグニチュードスケール で詳しく調べ, 従来知られていた, 大地震・中小地震の宇津・関公式とは, 別の関係式がある ことがわかつた，短周期地震計記録から再決定された実体波マグニチュードと地震モーメント の関係も調べられ, 合理的な仮定のもとに, 両地震マグニチュードは永よそ断層面積の平方 根の対数值に比例していることが明らかにされた.

（1）式の関係は, 例えば, 大地震だけの断層の長さを用いたマグニチニードとの関係 [BÅTH (1981)] 等から期待される関係と調和的である. したがつて，(1) 式について述べた比 例傾向はここで考えているデータセットだけについて云えるものではなく，より広い普遍性を もつと考える．また，(9) 式のもとになる (8) 式は非常に大きな稍深発・深発地震の地震モ ーメントと実体波マグニチュードの関係 [KANAMORI (1983)] に汪汴一致する.

地震の断層規模に比べ, これらマグニチニードを決める際に用いている地震波動は, はるか に短波長の波である. したがつて, 不均質断層破壊に伴らランダムな波動であると考光, 極值 統計の理論から, 地震マグニチュードについて考えてみた，これにより，短波長近似が成立す る範囲では, 地震マグニチュードは統計的にランダムな波動が重なり合い, その結果, 上に述 ベるような関係を示すことが理論的に示された。

巨大地震に関して,

$$
\log M_{0} \propto 3 M_{s}
$$

の関係が指摘されている [KANAMORI and ANDERSON (1975)]. 理論・観測から導かれる (6) 式を用いれば，上式は，

$$
\log S \propto 2 M_{s}
$$

となり，我々が経験的に導いた（1）式と等価な関係式を示す。つまり, 非常に大きい地震に 関していえば，(2) 式より（1）式の注うが現実的であることがわかる．そして，それは本論 で述べてあるように， $M_{s}$ を決める地震波振幅が大きい地震にたいして短波長の波動で支配さ 
れているからであると考えられる。

(26) 式は, AKI (1972) によれば, 震源スペクトルが短周期帯で周波数の自乗に逆比例して 減衰していることを示す. TAKEMURA and KoYAMA (1983) に依れば，(26) 式は島孤帯で発 生する長周期地震や津波地震でも成立している。したがつて, (27) 式の関係はそれらの地震で も成立していることが期待される.

不均質断層が破壊する時, 短周期地震波の励起が震源パラメータとどの様な関係にあるのか, (15)～(21) 式で考えた. 実際の地震発生過程では, マルチプルショックであつたり, 両方向 に破壊が伝播するなど，ここでは考えていない複雑さがあるだろう。しかし，単純化した議論 からわかることも少なくない。例えば，（21）式は短周期地震波のエネルギーが断層の長さや 幅に強く依存することを示す。 ランダム波動であるからェネルギーが加算可能な時系列となつ ている訳である.これは, 長周期近似から知れる断層面上の平均的くい違い量が断層の長さや 幅に比例する長周期地震学の結果と良い物理的対称を示している. また, この問題は (17) と (21) 式から推論されるように, 平均的な破壊伝播方向と短周期地震波の励起が密接な関係に あることを示している.

\section{文献}

ABE, K., 1981, Magnitudes of Large Shallow Earthquakes from 1904 to 1980, Phys. Earth Planet. Inter., 27, 72-92.

ABE., 1984, Complements to "Magnitudes" of Largs Shallow Earthquakes from 1904 to 1980, Phys. Earth Planet. Inter., 34, 17-23.

ABE, K. and H. KANAMORI, 1980, Magnitudes of Great Shallow Earthquakes from 1953 to 1977, Tectonophysics, 62, 191-203.

Adams, R. D., 1977, Survery of Practice in Determining Magnitudes of near Earthquakes, Part 2: Europe, Asia, Africa, Australia, the Pacific, World Data Center A, Rep. SE-8, pp. 1-65.

AKI, K., 1972, Scaling Law of Earthquake Source Time-function, Geophys. J., 31, 3-25.

ANG, A. H-S. and W. H. TANG, 1975, Probability concepts in engineering planning and design, Vol. 1. Basic principles, John Wiley \& Sons, New York, pp. 219-260.

BÅTH, M., 1981, Earthquake Magnitude-Recent Research and Current Trend, Earth Sci. Rev., $17,315-398$.

CARTWRight, D. E. and M. S. Longuet-Higgins, 1956, The Statistical Distribution of the Maxima of a Random Function, Proc. Roy. Soc. London, A237, 212-232.

Christoskov, L., N. V. Kondorskaya and J. VANEK, 1979, Homogeneous Magnitude System of the Eurasian Continent: P waves, World Data Center A, Rep. SE-18, pp. 1-42.

Gueller, R. and H. KanamoRI, 1977, Magnitudes of Great Shallow Earthquakes from 1904 to 1952, Bull. Seism. Soc. Am., 67, 587-598.

Gumbel, E. J., 1958, Statistics of extremes, Columbia Univ. Press, New York, pp. 75-254.

GUTENBERG, B. and C. F. RICHTER, 1954, Seismicity of the earth and associated phenomena, Princeton Univ. Press, Princeton, pp. 4-288.

KANAMORI, H., 1983, Magnitude Scale and Quantification of earthquakes, Tectonophysics, 93, 185-199.

KANAMORI, H. and D. L. ANDERSon, 1975, Theoretical Basis of Some Empirical Relations in Seismology, Bull. Seism. Soc. Am., 65, 1073-1095.

KANAMORI, H. and J. J. CIPAR, 1974, Focal Process of the Great Chilean Earthquake May 22, 1960, Phys. Earth Planet. Inter., 9, 128-136.

小山順二，1983，伝播性破壊確率モデルと地震の震源スペクトル，地震 II， 36，225-235. 
小山順二・武村雅之，1983，地震マグニチュードと震源過程について，地震 II，36，255-257.

KoYAMA, J. and S.-h. ZHENG, 1985, Excitation of Short-period Bodywaves by Great Earthquakes, Phys. Earth Planet. Inter., 37, 108-123.

小山順二・鄭 斯華・鈴木次郎，1984，巨大地震が励起したランダムな位相をもつ短周期実体波，地 震 II, 37, 655-669.

Lay, T., H. Kanamori and L. RufF, 1982, The Asperity Model and the Nature of Large Subduction Zone Earthquakes, Earthq. Predic. Res., 1, 3-71.

LEe, W. H. K. and R. J. Wetmiller, 1978, Survey of Practice in Determining Magnitudes of Near Earthquakes, Part 1: North, Central and South America, World Data Center A, Rep. SE-9, pp. 1-101.

Longuet-Higgins, M.S., 1952, On the Statistical Distribution of the Heights of Sea Waves, J. Mar. Res., 11, 245-266.

PurCaru, G. and H. Berkhemer, 1982, Quantitative Relations of Seismic Source Parameters and a Classification of Earthquakes, Tectonophysics, 84, 57-128.

SpaLL, H., 1980, Charles F. Richter-An Interview, Earthq, Inform. Bull., 12, 5-8.

武村雅之・小山順二, 1980，1秒実体波振幅からみた地震の規模評価, 地震学会講演予稿集, No. 2, 96.

TAKEMURA, M. and J. KoYama, 1983, Seismic Source Spectrum of Tsunami and Ordinary Earthquakes: A Quantitative Estimation of Tsunami from Forecoming Seismic Waves, Tohoku Geophys. J., 29, 115-128.

宇津徳治・関＼cjkstart彰，1954，余震区域の面積と本震のエネルギーとの関係，地震 II， 7, 233-240. 